\title{
National Identity, Constitutional Identity, and Sovereignty in the EU
}

\author{
Elke Cloots
}

\section{Introduction}

It is commonplace in European constitutional practice and theory to use the terms 'national identity' and 'constitutional identity' interchangeably. On the one hand, several Advocates General to the European Court of Justice have employed the concept of 'constitutional identity' to delineate what is protected under Article 4(2) TEU, even though, strictly speaking that Treaty provision refers to the Member States' national identities, inherent in their fundamental structures. ${ }^{1} \mathrm{On}$ the other hand, certain domestic constitutional courts which present themselves as the ultimate defenders of the identity of their constitution have pointed to Article 4(2) TEU to legitimate their assumed power to review secondary EU law against their constitutional identity. ${ }^{2}$ Against this background, it should not be a

1 See, e.g., Case C-53/04, Marrosu and Sardino, Opinion of AG Poiares Maduro, EU:C:2005:569, para 40; Case C-213/07, Michaniki, Opinion of AG Poiares Maduro, EU:C:2008:544, paras 31-33; Case C-399/11, Melloni, Opinion of AG Bot, EU:C:2012:600, paras 137-8 and 142; Case C62/14, Gauweiler, Opinion of AG Cruz Villalón, EU:C:2015:7, para 59.

2 See, esp., German Bundesverfassungsgericht, 2 BvE 2/08, 30 June 2009, paras 234, 240, 332 and 339; 2 BvR 2735/14, 15 December 2015, para 44. See also Spanish Constitutional Court, Declaración 1/2004, 13 December 2004, paras 35, 37-45 and 58; Sentencia 26/2014, 13 February 2014, para II.3; French Conseil Constitutionnel, Décision No 2004-505 DC, 19 November 2004, paras 10 and 12-13 juncto Décision No 2004-496 DC, 10 June 2004, para 7; Décision No 2006-540 DC, 27 July 2006, para 19; Décision No 2006-543 DC, 30 November 2006, para 6. But see German Bundesverfassungsgericht, 2 BvR 2728/13, 14 January 2014, para 29; Polish Trybunal Konstytucyjny, K 32/09, 24 November 2010, para III.2.1: 'An equivalent of the concept of constitutional identity in the primary EU law is the concept of national identity. ... The constitutional identity remains in a close relation with the concept of national identity, which also includes the tradition and culture'. 
surprise that, also in academic commentary, there is a strong tendency to equate national with constitutional identity. ${ }^{3}$

This article swims against the tide. It defies the conflation of national and constitutional identity prevalent in European constitutionalism. To this end, it makes three central points. First, it is submitted that the said conflation is not founded on a solid theory of legal interpretation. Second, this paper advances the argument that the obligation to respect the national identities of the Member States, as enshrined in Article 4(2) TEU, rests on different normative assumptions than the claim, made by certain constitutional courts, that European law must comply with constitutional identity for it to be applicable in the domestic legal order. Whereas the Union's obligation to pay heed to national identity is grounded in a liberal concern for the respectful treatment of the members of a multinational political community, the constitutional courts' preoccupation with constitutional identity rests on a particular conception of sovereignty. In other words, the demands for respect for national and constitutional identity are informed by distinct theoretical narratives. Third, it is argued that the Treaty makers had good reasons for writing into the EU Treaty a requirement of respect for the Member States' national identities rather than the States' sovereignty, or their constitu-

3 See, e.g., Leonard F.M. Besselink, 'National and Constitutional Identity before and after Lisbon,' Utrecht Law Review 6 (2010): 36, 37 and 43-4; Leonard F.M. Besselink, 'Respecting Constitutional Identity in the EU. Case Note to Case C-208/09, Ilonka Sayn-Wittgenstein v. Landeshauptmann von Wien, Judgment of the Court (Second Chamber) of 22 December 2010, nyr,' Common Market Law Review 49 (2012): 671, 672 and 682-3; Monica Claes, 'Negotiating Constitutional Identity or whose Identity Is it Anyway?' in Constitutional Conversations in Europe, ed. Monica Claes, Maartje de Visser, Patricia Popelier and Cathérine Van de Heyning (Antwerp: Intersentia, 2012), 205-6, 218 and 221; Pietra Faraguna, 'A Living Constitutional Identity: The Contribution of Non-Judicial Actors,' Jean Monnet Working Paper no 10/15, http://jeanmonnetprogram. org/paper/a-living-constitutional-identity-the-contribution-of-non-judicial-actors/, 7-11; Barbara Guastaferro, 'Beyond the Exceptionalism of Constitutional Conflicts: The Ordinary Functions of the Identity Clause,' Jean Monnet Working Paper no 01/12, http://centers.law.nyu.edu/ jeanmonnet/papers/12/1201.html, 8, 58 and 62-3; Theodore Konstadinides, 'Constitutional Identity as a Shield and as a Sword: The European Legal Order within the Framework of National Constitutional Settlement,' Cambridge Yearbook of European Legal Studies 13 (2010-1): 195, 197; Mattias Kumm and Victor Ferreres Comella, 'The Primacy Clause of the Constitutional Treaty and the Future of Constitutional Conflict in the European Union,' International Journal of Constitutional Law 3 (2005): 473, 492; Franz C. Mayer, 'Rashomon in Karlsruhe: A Reflection on Democracy and Identity in the European Union,' International Journal of Constitutional Law 9 (2011): 757, 765 and 781; François-Xavier Millet, 'National Constitutional Identity as a Safeguard of Federalism in Europe,' in Deconstructing EU Federalism through Competences, ed. Loic Azoulai, Lena Boucon and François-Xavier Millet, EUI Working Papers, Law 2012/06, http:// cadmus.eui.eu/bitstream/handle/1814/21298/LAW_2012_06_Rev2.pdf?sequence=3, 58; Denys Simon, 'L'identité constitutionnelle dans la jurisprudence de l'Union européenne,' in L'identité constitutionnelle saisie par les juges en Europe, ed. Laurence Burgorgue-Larsen (Paris: Éditions A Pedone, 2011), 27; Gerhard van der Schyff, 'The Constitutional Relationship between the European Union and its Member States: The Role of National Identity in Article 4(2) TEU,' European Law Review 37 (2012): 563, 567; Armin von Bogdandy and Stephan Schill, 'Overcoming Absolute Primacy: Respect for National Identity under the Lisbon Treaty,' Common Market Law Review 48 (2011): 1417, 1419 and 1435. 
tional identity, for that matter. The Treaties' focus on national identity should therefore be embraced and taken seriously.

\section{An unjustified conceptual leap}

Article 4(2) TEU requires the Union to respect the 'national identities [of the Member States], inherent in their fundamental structures, political and constitutional, inclusive of regional and local self-government'. This 'identity clause' was first introduced by the 1992 Treaty of Maastricht, albeit in a more concise form. Article $\mathrm{F}(1)$ of the original EU Treaty provided that ' $\mathrm{t}] \mathrm{he}$ Union shall respect the national identities of its Member States, whose systems of government are founded on the principles of democracy'. The reference to democracy was dropped in 1997, when the Amsterdam Treaty amended the identity clause as follows: 'The Union shall respect the national identities of its Member States' (old Art. 6(3) TEU). It was the 2009 Treaty of Lisbon that gave the identity clause its current shape, by limiting its scope to those manifestations of national identity that can be found in the Member States' fundamental political and constitutional structures.

It is purportedly the abovementioned Lisbon amendment that has led several commentators to conclude that the clause's initial reference to national identity had been de facto transformed into a reference to constitutional identity. ${ }^{4}$ This, however, is a conceptual leap that requires justification, and such justification is not offered by most scholars who defend this position. Their reading of the new identity clause does not seem to be based on a sound theory of legal interpretation. At best, there seems to be a tacit assumption that, by adding the said qualification to the identity clause, the drafters of the Lisbon Treaty sought to meet the demand from certain constitutional courts that EU law respect the identity of their constitutional order. ${ }^{5}$ Yet for at least two reasons such an assumption is inadequate to serve as a firm basis on which this shift in the meaning of the identity clause can be founded.

For one thing, there is no evidence in the travaux préparatoires of the identity clause confirming that the clause is rooted in the jurisprudence of those national constitutional courts. ${ }^{6}$ Nor do the preparatory materials make any mention of the concept of 'constitutional identity' or anything of the like. For another, giving a decisive role to the authors' intentions is a controversial method of ascertaining the meaning of a legal norm in the case of textual ambiguity. Several objections can indeed be raised against an 'intentionalist' approach to legal interpretation.

4 See, e.g., Besselink, 'National and Constitutional Identity,' 42-4; Faraguna, 'A Living Constitutional Identity,' 7 and 9; van der Schyff, 'The Constitutional Relationship between the European Union and its Member States,' 567-8; von Bogdandy and Schill, 'Overcoming Absolute Primacy,' 1419.

5 See, e.g., von Bogdandy and Schill, 'Overcoming Absolute Primacy,' 1419; Jan-Herman Reestman, 'The Franco-German Constitutional Divide. Reflections on National and Constitutional Identity,' European Constitutional Law Review 5 (2009): 374, 380.

6 See also Reestman, 'The Franco-German Constitutional Divide,' 380. 
First, the intentionalist faces practical obstacles to discovering the relevant intentions. Even if the legislative history of a norm can be consulted, as is for example the case for the Lisbon amendment to the identity clause, ${ }^{7}$ important difficulties remain: Whose and what sort of intentions matter? The intentions of the particular official who proposed the amendment, of the Member State delegates who supported it, of the chairman of the Convention working group that prepared the amendment, of the Commission? And are the relevant intentions merely those concerning the general objectives of the amendment (e.g., to enhance transparency, ${ }^{8}$ to protect the Member States ${ }^{9}$ ), or do they also include drafters' opinions about, for example, the ways to achieve those ends (e.g., by designating 'areas of core national responsibilities' ${ }^{\prime 10}$ ) or the content of a specific legal term (e.g., 'national identity' $\left.{ }^{11}\right)$ ?

Second, using this sort of subjective intentions as a tool for interpreting the law has provoked more fundamental objections from leading legal theorists, including Joseph Raz, ${ }^{12}$ Ronald Dworkin ${ }^{13}$ and Jeremy Waldron. ${ }^{14}$ They criticise intentionalists for making the law's legitimacy, that is, what makes the law worthy of respect and obedience, dependent on a supposed authority of the authors' opinions and beliefs. In their view, individual decision-makers lack the authority that is necessary to legitimate law's normative power.

In addition to the abovementioned practical and principled objections, it should be noted as a final point, that there is no intentionalist tradition of Treaty interpretation in the EU anyway. When called upon to interpret a Treaty provision, the Court of Justice does not habitually scan historical documents in a search for the intentions of the Treaty makers. Hence it seems unlikely that the Union institutions, the Member States or EU citizens would feel that their just expectations are disregarded if the Court failed to give effect, in its interpretation of a norm of primary EU law, to the opinions expressed in the drafting history of the Treaty. It follows that an intentionalist approach cannot find support in a doctrine of respect for legitimate expectations either.

7 Working documents of Working Group V, which prepared the amendment, have been published on the website of the European Convention http://european-convention.eu.int.

8 See, e.g., Final report of Working Group V, CONV 375/1/02 REV 1, 4 November 2002, 10 and 12.

9 Ibid., 11.

10 Ibid., 11. See also Paper by Mr Henning Christophersen, Working Group V, Working Document 5, 11 July 2002.

11 Paper of the Chairman Mr Henning Christophersen, Working Group V, Working Document 28, 24 September 2002, 5; Final report of Working Group V (n. 57) 11-12.

12 Joseph Raz, 'Intention in Interpretation' in Joseph Raz, Between Authority and Interpretation (Oxford: Oxford University Press, 2009), 265-98.

13 Ronald Dworkin, 'How Law Is like Literature,' in Ronald Dworkin, A Matter of Principle (Oxford: Clarendon Press, 2001), 146-66.

14 Jeremy Waldron, 'Legislators' Intentions and Unintentional Legislation,' in Law and Interpretation. Essays in Legal Philosophy, ed. Andrei Marmor (Oxford: Clarendon Press, 1995), 352-6; Jeremy Waldron, 'Legislating with Integrity,' Fordham Law Review 72 (2003): 373, 386-8. 
It is, of course, one thing to say that a reading of Article 4(2) TEU that focuses on constitutional identity lacks grounding in a sound theory of legal interpretation, but it is quite another to ascertain how the meaning of the Treaty provision should be retrieved. Elsewhere I have made an argument for an interpretation of Article 4(2) TEU that is based on the text of the provision, on the way it has come to be understood in the practices of the Union institutions, and on the principles of political morality that undergird the provision. ${ }^{15}$

The text of Article 4(2) TEU, to start with, speaks of the 'national identities [of the Member States], inherent in their fundamental structures, political and constitutional, inclusive of regional and local self-government'. Thus, judging by the text, the identity clause protects a Member State's national identity as it finds expression in the State's fundamental structures, most notably its constitution. One example of such 'fundamental structures' that may mirror a State's national identity is expressly cited in the text: those concerning regional and local autonomy.

Since the entry into force of the Lisbon Treaty, the ECJ has, on a few occasions, pronounced on the meaning of 'national identity' as protected under the identity clause. According to the Court, the national identities of the Member States referred to in Article 4(2) TEU include, amongst other things, 'the status of the State as a Republic ${ }^{\prime 16}$ and 'protection of a State's official national language'. ${ }^{17}$

Yet despite the clarifications that have been made to the concept of "national identity' in the text of Article 4(2) TEU as well as in a number of ECJ judgments, the notion remains - to a large extent - vague and ambiguous. In cases where the text of the identity clause does not bring solace and no relevant case law yet exists, an interpretation of the clause founded on moral reasoning would be the most promising avenue for the ECJ to follow. In other words, when the content of the identity clause is indeterminate, the Court should base its reading of the clause on moral principles, that is, on the value or merit behind the identity clause. The following section sets out those values and shows that they differ from the normative assumptions underlying the constitutional identity doctrine as articulated by the constitutional courts of certain Member States.

\section{The national identity versus the state sovereignty narrative}

What are the moral background principles to which the identity clause gives effect? To cut a long story short, national identity ought to be respected by the Union, not because nations are valuable for their own sake but because the individual members of a national community have a compelling interest in the respectful treatment of their nation. Respect for nations and the people who feel attached to them is conducive to the realisation of six valuable, liberal goods. Those goods 
include individual autonomy, distributive justice, deliberative democracy, justice as equal respect, liberty, and the viability of the common, multinational political community. The former three liberal virtues are often considered to be goods that can best be achieved within the context of thriving, politically autonomous national groups, which deserve to be respected for that. The latter three, in contrast, are virtues stemming directly from national identity being respected by the central institutions of a multinational polity. Each of those goods is briefly described in the following paragraphs.

A first good that national societies are thought to help produce - and hence a first reason to treat nations with respect - relates to individual autonomy. More particularly, it has been claimed by liberal nationalists like Will Kymlicka that national societies provide individuals with a context in which they can exercise their autonomy in a meaningful way. To put it in Kymlicka's own terms, 'freedom involves making choices amongst various options, and our societal culture not only provides these options, but also makes them meaningful to us' ${ }^{18}$ By a 'societal culture', Kymlicka understands 'a territorially-concentrated culture, centred on a shared language which is used in a wide range of societal institutions, in both public and private life (schools, media, law, economy, government, etc.). ${ }^{19}$ Nations constitute the paradigm case of such a societal culture. ${ }^{20}$

A second liberal ideal to which national societies are instrumental is distributive or social justice. The view is commonly held that distributive justice is easier to realise in a political community where citizens share a national identity. Welfare redistribution through fiscal and social policies presupposes a willingness to pursue solidarity among the members of the political community, that is, a readiness to make (financial) sacrifices for one's fellow citizens. People will more likely be prepared to make such sacrifices if they identify with the potential beneficiaries and if they trust the latter to show solidarity with them when they are in need of support. Liberal nationalists believe that a common national identity offers the best prospect of citizens identifying with, and having faith in, each other. ${ }^{21}$

A third liberal good which is commonly associated with national societies is deliberative democracy. Deliberative democracy is predicated on the assumption that genuinely democratic decision-making requires more than casting votes: it also presupposes public participation in deliberation and discussion. A common national identity facilitates the attainment of this ideal in at least two ways. First,

18 Will Kymlicka, Multicultural Citizenship (Oxford: Oxford University Press, 1995), 83. See also David Miller, On Nationality (Oxford: Clarendon Press, 1995), 42-5; Avishai Margalit and Joseph Raz, 'National Self-Determination,' in Joseph Raz, Ethics in the Public Domain, 2nd ed. (Oxford: Clarendon Press, 2001), 134-5; Joseph Raz, 'Multiculturalism: A Liberal Perspective,' in Raz, Ethics in the Public Domain, 175-7; Yael Tamir, Liberal Nationalism (New Jersey: Princeton University Press, 1993), 18 and 32-4.

19 Will Kymlicka, Politics in the Vernacular (Oxford: Oxford University Press, 2001), 25. See also Kymlicka, Multicultural Citizenship, 18 and 76.

20 Kymlicka, Multicultural Citizenship, 80 and 93.

21 Kymlicka, Politics in the Vernacular, 225. 
when citizens are tied by linguistic and national bonds they experience fewer difficulties in communicating with one another, which benefits, in turn, the democratic debate, not only in the decision-making bodies but also in the media. Secondly, democracy can only work if there is sufficient confidence and trust among citizens themselves and among citizens and politicians. Only if people are convinced that their fellow citizens are interested in their opinions too and only if the losers in this election or debate are assured of a chance to win next time is true democracy possible. Moreover, in an indirect democracy, citizens need the confidence that their interests will be genuinely represented in parliament. Liberal nationalists believe that the high level of trust democracy requires is most likely to exist if citizens share a national identity. ${ }^{22}$

Admittedly, one may object that the conditions for individual freedom, distributive justice and deliberative democracy need not necessarily be shaped and maintained at the Member State level. Indeed, in a multinational polity like the EU, the argument from individual autonomy, social justice, and democracy may well work in favour of European nation-building and against the preservation of the Member States' national identities, rather than the other way around. However, this objection overlooks the close ties between people and their own national group. As is explained below, it may be feared that nation-building at the EU level for the sake of a European societal culture, distributive justice and deliberative democracy will come at the price of injustice as unequal dignity or respect. Though it cannot be excluded that, in the long term, the EU itself will become a fertile ground for the realisation of those liberal virtues, it may be argued that, at present, these goods are still largely the realm of sub-EU national groups, which deserve to be respected for that.

The reasons for lauding the inclusion of the identity clause that we have discussed so far all bear on the importance of national societies. Yet there are three additional and perhaps even stronger reasons for welcoming the identity clause, which are of a slightly different nature. Here, the focus is not on benefits associated with the presence of a common national identity in a political community but rather on goods that are realised when a multinational political community pays respect to the national identities of its constitutive political entities and their citizens. These goods include justice as equal respect, liberty, and the viability of the multinational polity. Unlike the three preceding arguments in favour of respect for national identity, the arguments to come have no particular link with liberal nationalist thought.

It has been noted that a lack of respect on the part of the central polity level for the national identities of the sub-polity units and their members is unjust. But in 
what does this injustice reside? It seems that many of its advocates ${ }^{23}$ ground the injustice thesis in the double assumption that individuals have a vital interest in political respect and recognition for their identity and that part of what constitutes an individual's identity are her social affiliations, including - in many cases $^{24}$ - membership in her national group. ${ }^{25}$ If people feel that their identities are not respected by their political institutions, or not treated with equal respect and dignity, then they are likely to experience their treatment as grossly unjust.

A second reason why respect for national identities on the part of a multinational political community like the EU may be thought to be a good thing is that it is supposed to be a safeguard for individual liberty. A leading advocate of this thesis is Jacob Levy. His view is that, in a political community in which public power is divided between the central level and smaller units, it is of vital importance that citizens remain loyal to those smaller units. ${ }^{26}$ In the absence of such loyalty, Levy fears that the smaller units cannot serve as a genuine counterweight for the central polity's (potential) desire to aggregate power. As a result, public power risks being increasingly concentrated in the hands of central government and this tendency toward centralisation may threaten individual liberty. ${ }^{27}$ The citizens' loyalty to their respective sub-entities must be strong enough to rival their loyalty to the central polity level, and Levy considers ethno-cultural and linguistic attachments to the sub-entities to be particularly suitable in generating such a robust loyalty. ${ }^{28}$ It is therefore important that those ethno-cultural and linguistic identities be respected within the larger political community.

23 Will Kymlicka, however, seems to put greater emphasis on individual autonomy. See Helder De Schutter, 'The Linguistic Territoriality Principle - A Critique,' Journal of Applied Philosophy 25 (2008): 105, 108. Joseph Raz and Helder De Schutter deploy both individual freedom and identity valuation as a basis for their injustice-thesis. See De Schutter, 108; Margalit and Raz, 'National Self-Determination,' 133-9. Philippe Van Parijs, for his part, seems to prefer the argument based on a person's valuation of her identity. See Philippe Van Parijs, 'Linguistic Justice and the Territorial Imperative,' Critical Review of International Social and Political Philosophy 13 (2010): 181, 186 ('This strengthening of the argument does not rely on anything like a holistic right of each language to survive, or to have a fair chance to survive. Nor does it appeal to the need to preserve the societal culture associated with a particular community's inherited language as a necessary component of the resources required for leading a meaningful life').

24 As Bhikhu Parekh has noted, different people may attach weight to different social affiliations as well as different weights to the same social affiliations. Moreover, a single individual may evolve over time and identify with other social roles than she previously did. Bhikhu Parekh, 'Logic of Identity,' Politics, Philosophy and Economics 8 (2009): 267, 273-6.

25 See, e.g., De Schutter, 'The Linguistic Territoriality Principle - A Critique,' 107-8; Avishai Margalit and Moshe Halbertal, 'Liberalism and the Right to Culture,' Social Research 61 (1994): 491, 501-6; Bhikhu Parekh, A New Politics of Identity: Political Principles for an Independent World (NY: Palgrave Macmillan, 2008), 41-59; Tamir, Liberal Nationalism, 72-7; Raz, 'Multiculturalism,' 178; Philippe Van Parijs, Linguistic Justice for Europe and for the World (Oxford: Oxford University Press, 2011), 117-20.

26 Jacob T. Levy, 'Federalism, Liberalism, and the Separation of Loyalties,' American Political Science Review 101 (2007): 459, 464-6.

27 Ibid., 464-6 and 472.

28 Ibid., 466-8. 
A final good to which respect for a multinational polity's distinct national groups is often said to be instrumental is the viability of the multinational polity itself. Given that its citizens identify with distinct national groups (either at the polity or sub-polity level), the viability of a multinational polity may be precarious. The previous point on individual liberty indicates why this is so: people's loyalty to their national group is often so strong that it is able to rival their loyalty to the larger political community in which their nation is embedded. The advantage of citizens' solid loyalty to their own national group is, as we have just seen, that the exercise of power at the central polity level does not go unchecked. The potential downside of this strong national allegiance, however, is that the legitimacy and authority of the larger polity are not taken for granted by its citizens, which may endanger the stability and even the continued existence of the polity. ${ }^{29}$ Hence, it is felt necessary to devise means for assuring multinational citizens' loyalty to their common political community. There has been a lively debate among political philosophers about what could bind the citizens of a multinational polity in a sufficiently durable way to their common political community. This is not the place to dig into the details of that debate. Suffice it to say for the present that, in order to gain the loyalty of its citizens, a multinational political community should make sure that citizens do not feel excluded or alienated from its institutions and practices - citizens are unlikely to endorse institutions or practices in that case. ${ }^{30}$ To guarantee that a political community is truly inclusive so that all its citizens feel 'at home', citizens must feel that their identity, including their national identity, is respected. Consequently, and even though it might sound paradoxical, a multinational polity like the EU will need to pay heed to the loyalties its citizens feel towards their own national groups if it itself desires to become the object of its citizens' allegiance in order to secure its viability.

So far, this article has attempted to demonstrate that there is particular value in respecting national identity in a multinational polity such as the EU and that the identity clause of Article 4(2) TEU finds, therefore, at least part of its justification in moral principle. It is the moral concerns underlying the identity clause, rather than the intentions of its authors, that should guide the ECJ's reasoning in cases where the meaning of the identity clause is uncertain. What particular implications such a 'moral reading' of the identity clause may have, has been explored in detail elsewhere. ${ }^{31}$ For present purposes, suffice it to recall one of the main conclusions of that study: the identity clause protects the features that make a national community what it is (e.g., its history, language, values, traditions), and

29 See also Kymlicka, Multicultural Citizenship, 181-2; Sujit Choudhry, 'Citizenship and Federations: Some Preliminary Reflections,' in The Federal Vision. Legitimacy and Levels of Governance in the United States and the European Union, ed. Kalypso Nicolaidis and Robert Howse (Oxford: Oxford University Press, 2001), 387-90.

30 Andrew Mason, Community, Solidarity and Belonging. Levels of Community and their Normative Significance (Cambridge: Cambridge University Press, 2000), 137-9; Helder De Schutter, 'European Ties that Bind: Political or Cultural?' in Federalism in the European Union, ed. Elke Cloots, Geert De Baere and Stefan Sottiaux (Oxford: Hart Publishing, 2012), 185. See also Kymlicka, Multicultural Citizenship, 183, 185 and 189.

31 Cloots, National Identity in EU Law, 139-91. 
without which the community would no longer be the same, in so far as those features are mirrored in fundamental domestic structures, most notably constitutional law. Whether these structures are part of the identity of the domestic constitution, in the sense that they individuate the constitution and mark it out from others, is not relevant under Article 4(2) TEU. Nor should it be, given that national identity has an independent moral claim to respect from the Union. Conversely, norms belonging to a State's constitutional identity which do not incorporate an aspect of national identity do not fall within the scope of Article 4(2) TEU. ${ }^{32}$

Article 4(2) TEU's focus on national identity stands in sharp contrast to the preoccupation of certain domestic constitutional courts with constitutional identity. If the reasons why the Union ought to respect national identity are so compelling, why do constitutional courts use a different rhetoric, centred on the identity of their constitution?

One possible explanation is obviously that constitutional courts are established precisely to defend the national constitution. Protecting the constitution is simply what constitutional courts do, it is even the reason of their existence. In fulfilling their task, constitutional courts generally do not only care about the norms of their constitution which give expression to the State's national identity, although their jurisdiction may well be limited to infringements of specific constitutional provisions. ${ }^{33}$ Moreover, it seems only natural that a constitutional court's primary concern is with those provisions which it considers part of the very identity of the constitution, that is, with the provisions that individuate the constitution and without which the constitution would no longer be the same. ${ }^{34}$

No doubt there is much truth in this argument, and it certainly helps explain why national acts are subject to constitutional review carried out by a constitutional court. However, it does not suffice, in itself, to justify why the Union, that is, a different legal system, should also be bound by national constitutional norms and have its actions reviewed by domestic constitutional courts. It is not axiomatic that the laws of one legal system must comply with norms originating in another system in order to be valid. Hence national constitutional courts need to come up with an additional reason to justify their assertion that Union legislation must respect the identity of their constitution, and to legitimise their power to engage in such identity review.

Many national constitutional courts have understood this, and have developed a theoretical basis for their claim that EU law must comply with the identity of their constitution. Significantly, they do not derive their theory from the afore-

32 This is not to deny that such norms may be covered by other basic precepts of EU law, such as Arts. 52(4) and 53 of the EU Charter of Fundamental Rights and the fundamental rights clause contained in Art. 6(3) TEU, all of which allude to the Member States' constitutions.

33 See, e.g., Art. 142 of the Belgian Constitution and Arts. 1 and 26, §1, Bijzondere wet op het Grondwettelijk Hof.

34 Cloots, National Identity in EU Law, 167. 
mentioned principles of political morality that call on the Union to respect national identity but rather from a particular conception of sovereignty. The foundation of the requirement of respect for constitutional identity in a sovereignty claim has been most clearly articulated by the German Constitutional Court. The notion of sovereignty is ubiquitous in its Lisbon Urteil, the ruling in which the Court proclaimed that its acceptance of the primacy of EU law is subject to the latter's compliance with constitutional identity. ${ }^{35}$ More specifically, the Court described the so-called 'eternity clause' in the German constitution ${ }^{36}$ as a guarantee of its constitutional identity and, therefore, of 'sovereign statehood for Germany'. ${ }^{37}$ It also stated that the 'transfer of sovereign powers to the European Union' is conditional on the maintenance of 'the sovereign statehood of a constitutional state (...) on the basis of an integration programme according to the principle of conferral and respecting the Member States' constitutional identity' ${ }^{38}$ Throughout the judgment, the Court made it abundantly clear that it conceives of the Union as a treaty-based association of States which remain sovereign and are 'the masters of the Treaties' (Staatenverbund). ${ }^{39}$ In such a Verbund, the identity of the domestic constitution cannot be transferred to the Union, and it is for the national constitutional courts to review whether the law of the Union does not transgress these constitutional limits. ${ }^{40}$

The German Constitutional Court reiterated the sovereignty-based justification of this 'constitutional identity lock' in more recent decisions. Thus, in its 2014 Gauweiler order, the Court ruled that Union law affecting German constitutional identity would be inapplicable in Germany, because the domestic legislature cannot transfer to the Union sovereign powers the exercise of which would affect German constitutional identity. ${ }^{41}$ Moreover, the Court reaffirmed in this ruling its power to engage in constitutional identity review of EU law. ${ }^{42}$ In a similar vein, the Court decided in an order of 15 December 2015 that its constitutional identity review matches the special nature of the Union as a Verbund that is ultimately founded on international treaties concluded by the Member States, which remain the Herren der Verträge. ${ }^{43}$

A comparable link between constitutional identity and State sovereignty has also been established by other constitutional courts. In a 2004 ruling on the EU Con-

See also Jo E.K. Murkens, "We Want our Identity Back" - The Revival of National Sovereignty in the German Federal Constitutional Court's Decision on the Lisbon Treaty,' Public Law (2010): 530, 538; David Thym, 'In the Name of Sovereign Statehood: A Critical Introduction to the Lisbon Judgment of the German Constitutional Court,' Common Market Law Review 46 (2009): 1795, 1797-1805. Art. 79.3 of the German Basic Law.

37 Bundesverfassungsgericht, 2 BvE 2/08, 30 June 2009, para 216.

38 Ibid., para 226.

39 Ibid., paras 229, 231, 235, 263, 271, 277-81, 298, 329, 334, 339, 343, 346-7.

40 Ibid., paras 230, 235, 239-41, 332, 334, 336, 339.

41 Bundesverfassungsgericht, 2 BvR 2728/13, 14 January 2014, para 27.

42 Ibid.

43 Bundesverfassungsgericht, 2 BvR 2735/14, 15 December 2015, para 44. See also para 47. 
stitutional Treaty, the Spanish Constitutional Court emphasised that the Spanish State, more particularly the Spanish people, has retained sovereignty, ${ }^{44}$ and that the State's sovereign powers can be limited only if and insofar as EU law remains compatible with the fundamentals, that is, the identity, of the Spanish Constitution. ${ }^{45}$ This doctrine has been lately reasserted in the Melloni case. ${ }^{46}$ An analogous line of reasoning is apparent in the case law of certain Eastern European constitutional courts. Stressing the sovereignty of the Czech Republic and depicting the Member States as the 'masters of the Treaties', 47 the Czech Constitutional Court concluded in its Lisbon rulings that (at least) the 'material core' of the constitution takes precedence over Union law, and arrogated the power to review the compatibility of Union law with 'the identity of values' ${ }^{48}$ The Polish Constitutional Court, for its part, portrayed the EU as an international organisation of sovereign States in its 2010 decision concerning the European Arrest Warrant. From this claim to State sovereignty, the Court inferred that powers relating to Polish constitutional identity cannot be conferred upon the Union. ${ }^{49}$ Finally, it is noteworthy that the UK Supreme Court now openly sympathises with the constitutional identity concerns voiced by certain constitutional courts. ${ }^{50}$ The nub of the Supreme Court's reasoning is, again, the idea that sovereignty rests with the United Kingdom, more particularly with the UK Parliament. ${ }^{51}$

The above analysis allows us to conclude that the constitutional identity doctrine developed by certain domestic courts is essentially premised on an assertion of State sovereignty. The national identity clause embedded in Article 4(2) TEU, by contrast, should be regarded as the instantiation of basic moral principles that require a multinational political community to show respect for the identity of its constituent national groups. Given this different normative pedigree, it becomes hard to maintain that constitutional identity, as defined by the highest judicial bodies of the Member States, is what is protected under Article 4(2) TEU. Surely there may be considerable overlap between a Member State's constitutional identity and its national identity as reflected in its fundamental structures. ${ }^{52}$ Yet it would be misguided to simply equate the predicate of the EU Treaty's identity clause with 'constitutional identity'. A separate question is, of course, whether the Treaty makers would have done better to include a requirement of respect for the

44 Spanish Constitutional Court, Declaración 1/2004, 13 December 2004, paras 37, 47, 50 and 58.

45 Ibid., paras 37 and 58.

46 Spanish Constitutional Court, Sentencia 26/2014, 13 February 2014, para II.3.

47 Czech Constitutional Court, Pl ÚS 19/08, 26 November 2008, paras 96-108 and 216; Pl ÚS 29/09, 3 November 2009, paras 146-9. See also Pl ÚS 5/12, 31 January 2012.

48 Czech Constitutional Court, Pl ÚS 19/08, 26 November 2008, paras 110-11, 120 and 216; Pl Ús 29/09, 3 November 2009, paras 150 and 172. See also Pl ÚS 5/12, 31 January 2012.

49 Polish Constitutional Court, K 32/09, 24 November 2010, para III.2.1. See also paras III.1.1.2, III.2.2, III.3.1 and III.3.8.

50 UK Supreme Court, Pham v. Secretary of State for the Home Department, 25 March 2015, [2015] UKSC 19, paras 90-91.

51 Ibid., paras 76 and 80.

52 See also Cloots, National Identity in EU Law, 167. 
Member States' sovereignty, or constitutional identities, rather than the States' national identities. It is to this issue that we now turn.

\section{The Treaty reference to national identity: not a bad idea after all}

As such, the concept of State sovereignty - or of sovereignty altogether - does not appear in the Union's basic Treaties. Including a requirement of respect for the Member States' sovereignty would have been a sensible option though. Not only is sovereignty something that Member States care deeply about; the protection of State sovereignty is also a recurrent theme in US constitutional law, which has often served as a model for the development of primary EU law. Whilst the text of the US Constitution does not make mention of 'sovereignty', the US Supreme Court has read a safeguard of State sovereignty into the Tenth Amendment to the Constitution, ${ }^{53}$ which contains a principle akin to the EU's principle of conferral. ${ }^{54}$ As the US Supreme Court has reiterated many times, 'State sovereignty is not just an end in itself: "Rather, federalism secures to citizens the liberties that derive from the diffusion of sovereign power." 55 Does US constitutional law give us reason to regret the path chosen in the EU Treaty, which is the path of respect for national identity rather than State sovereignty? This may be doubted for at least three reasons.

First, the EU differs from the US in a fundamental respect: whereas the EU is essentially a multinational polity, the US is a mono-national federation. As was explained above, there are compelling moral arguments militating in favour of respect for the national identities of the constituent entities of a multinational polity like the EU. Although the imposition of a prohibition on the Union intruding on Member States' sovereign powers may certainly be conducive to a respectful treatment of the States' national identities, ${ }^{56}$ it would not suffice. Other instruments for showing esteem for national identity are equally, if not even more, important; in particular national differentiation in EU law, and symbolic recognition of the Union's multinational character. ${ }^{57}$ A narrow focus on State sovereignty in the Treaties would overlook these other promising and indispensable methods through which the Union may pay respect to national identity and meet the moral claims of its constituent national groups. Consequently, in a multinational polity like the EU, a national identity - rather than sovereignty-centred approach - seems to be perfectly justified.

54 The Tenth Amendment reads as follows: 'The powers not delegated to the United States by the Constitution, nor prohibited by it to the States, are reserved to the States respectively, or to the people.' Compare Art. 5(2) TEU.

55 See, e.g., New York v. United States, above n. 53, 181; Bond v. United States, 564 US (2011); National Federation of Independent Business v. Sebelius, 567 US_(2012).

56 See in more detail Cloots, National Identity in EU Law, 171-2.

57 See in more detail ibid., 175-80. 
Second, including in the Treaties a reference to State sovereignty as understood by the constitutional courts of certain Member States would have been difficult to square with the Union institutions' own view of the locus of sovereignty. As has been convincingly argued by Gráinne de Búrca, the supremacy doctrine of the Court of Justice can be construed as a claim to sovereignty on behalf of the Union. Although a doctrine of supremacy is not necessarily founded on an assertion of sovereignty, a sovereignty claim seems to lie at the basis of the ECJ's reasoning in Costa v. ENEL, the judgment in which the supremacy of EU law was established. ${ }^{58}$ The insertion of a requirement of respect for constitutional identity as conceived by those constitutional courts would, of course, have presented a similar difficulty. Advocate General Cruz Villalón made this point succinctly clear in his Opinion in Gauweiler:

[It] seems to me an all but impossible task to preserve this Union, as we know it today, if it is to be made subject to an absolute reservation, ill-defined and virtually at the discretion of each of the Member States, which takes the form of a category described as "constitutional identity". (...)

Such a "reservation of identity", independently formed and interpreted by the competent - often judicial - bodies of the Member States (of which, it need hardly be recalled, there are currently 28) would very probably leave the EU legal order in a subordinate position, at least in qualitative terms. ${ }^{59}$

In the absence of a theory of sovereignty on which both the Member States and the Union can agree, it is plausible to assume that any Treaty reference to sovereignty would become a source of new tension and conflict. In this respect, too, the EU is different from the US. Unlike in the EU, there is a shared narrative of sovereignty that is widely accepted in the US: the federal Constitution permanently divided sovereignty between the nation and the States. ${ }^{60}$ Admittedly, there used to be rival theories of sovereignty in the US as well; agreement on the location of sovereignty was not achieved overnight. ${ }^{61}$ That being said, there are no obvious signs of an emerging convergence on a common European theory of sovereignty, despite valuable scholarly attempts to develop such a theory. ${ }^{62}$ On the contrary,

58 Gráinne de Búrca, 'Sovereignty and the Supremacy Doctrine of the European Court of Justice,' in Sovereignty in Transition, ed. Neil Walker (Oxford: Hart Publishing, 2003), 450-5. See also Hans Lindahl, 'Sovereignty and Representation in the European Union,' in Sovereignty in Transition, 109.

59 Case C-62/14, Gauweiler, Opinion of AG Cruz Villalón, EU:C:2015:7, paras 59-60.

60 See, e.g., US Supreme Court, McCulloch v. Maryland 17 US 316, 410 (1819).

61 See Jeffrey Goldsworthy, 'The Debate about Sovereignty in the United States: a Historical and Comparative Perspective,' in Sovereignty in Transition, 423-46; Robert Schütze, From Dual to Cooperative Federalism. The Changing Structure of European Law (Oxford: Oxford University Press, 2009), 76-77.

62 See, e.g., Matej Avbelj, 'Theory of European Union,' European Law Review 36 (2011): 818; Stefan Rummens and Stefan Sottiaux, 'Democratic Legitimacy in the Bund or "Federation of States": the Cases of Belgium and the EU,' European Law Journal 20 (2014): 568; Schütze, From Dual to Cooperative Federalism, 72-73. 
as demonstrated above, national constitutional courts increasingly resort to a rhetoric of constitutional identity that is founded on a claim to State sovereignty. At the same time, it is equally clear that the ECJ is unwilling to give up on the idea that the Union, too, has sovereign status. ${ }^{63}$ In reaction to the fact that conflicting opinions on the subject are so strongly held, there is a tendency in European legal theory either to abandon the concept of sovereignty altogether, ${ }^{64}$ or to develop a theoretical scheme that is able to accommodate the rival sovereignty claims currently made at national and EU level. ${ }^{65}$ Against this backdrop, it seems unlikely that a widely shared view of the locus of sovereignty in Europe will emerge any time soon. Given the contentious character of the notion of sovereignty in the EU, the EU Treaty's focus on national identity provides an attractive alternative. It avoids that either the national constitutional courts or the ECJ have to drop their own sovereignty and supremacy claims. It avoids, in other words, anyone having to admit defeat, ${ }^{66}$ which makes it easier for judicial bodies at both levels to embrace this Treaty provision, and may even turn the identity clause into a vehicle of judicial dialogue. ${ }^{67}$

A third reason for favouring a national identity approach over a State sovereignty approach in the Treaties is that, also in the US, the appeal of the idea that mutually exclusive spheres of sovereign powers coexist at the national and the State level has gradually declined. As Robert Schütze explains with characteristic clarity, this model of dual federalism was abandoned in the middle of the twentieth century and replaced by a new model, which he calls cooperative federalism. ${ }^{68}$ In Schütze's view, cooperative federalism is a suitable constitutional theory for Europe as well. Also in the EU, the States' exclusive sphere of power has been progressively reduced ${ }^{69}$ and the two levels of government increasingly cooperate within the areas of shared powers, for instance through minimum harmonisation at Union level. ${ }^{70}$ What is more, the principle of subsidiarity, enshrined in Article 5(3) TEU, can be regarded as a constitutional commitment on the part of the

63 See, in particular, Opinion 1/09, 8 March 2011, EU:C:2011:123, para 65; Opinion 2/13, 18 December 2014, EU:C:2014:2454, para 157, in which the Court reiterated the reasoning it articulated in Costa v. ENEL with a view to legitimating its doctrine of EU supremacy. Significantly, the qualification 'albeit within limited fields', which the Court had added to its observation that 'the Member States have limited their sovereign rights', has now been replaced by 'in ever wider fields'.

64 See, e.g., Neil MacCormick, 'On Sovereignty and Post-Sovereignty,' in Neil MacCormick, Questioning Sovereignty (Oxford: Oxford University Press, 1999), 123-36. See also Pavlos Eleftheriadis, 'Law and Sovereignty,' Law and Philosophy 29 (2010): 535.

65 See, e.g., Nick W. Barber, 'Legal Pluralism and the European Union,' European Law Journal 12 (2006): 306; Miguel Poiares Maduro, 'Contrapunctual Law: Europe's Constitutional Pluralism in Action,' Sovereignty in Transition, 501-37.

66 Compare Barber, 'Legal Pluralism and the European Union,' 328.

67 See also Mary Dobbs, 'The Shifting Battleground of Article 4(2) TEU: Evolving National Identities and the Corresponding Need for EU Management?' European Journal of Current Legal Issues 21 (2015).

68 Schütze, From Dual to Cooperative Federalism, 75-126.

69 Ibid., 129-88.

70 Ibid., 189-240. 
Union to the spirit of cooperation. ${ }^{71}$ Like the subsidiarity principle, the principle of respect for the national identities of the Member States fits neatly into the model of cooperative federalism. As has been argued elsewhere, the identity clause mandates nation-sensitive European law making and interpretation, and publicly recognises the multinational composition of the EU. ${ }^{72}$ These methods of accommodating the Member States' interests, i.e., group-differentiation and recognition, are of increasing importance when both the autonomy of the Member States and their impact (individually and collectively) on the European decisionmaking process diminish. Carving out mutually exclusive spheres of sovereignty, in contrast, emanates from a desire to return to a past that is lost and gone, but will probably do little to protect national interests in a Europe where policy areas have become more and more intertwined. ${ }^{73}$

\section{Conclusion}

This essay has attempted to challenge the assumption - often taken for granted that what Article 4(2) TEU protects is, in fact, constitutional identity, even though the Treaty provision speaks of national identity. It has been contended, first, that a reading of Article 4(2) TEU through the lens of constitutional identity does not rest on a sound theory of legal interpretation. Second, it has been demonstrated that a requirement of respect for constitutional identity, at least as envisioned by several domestic constitutional courts, is premised on a different normative proposition than the Treaties' requirement of respect for national identity. Whereas the constitutional identity doctrine articulated by certain national courts is based on a claim to sovereignty on behalf of the Member States, the national identity clause laid down in Article 4(2) TEU implements fundamental principles of political morality, which call on a multinational polity to pay heed to the identity of its constituent national communities.

A distinct but related issue addressed in this paper is whether it would have been better if the Treaties had concentrated on respect for the Member States' sovereignty, or constitutional identities, rather than the States' national identities. This question was answered in the negative. The Union's multinational character, the lack of a single theory of sovereignty that is generally endorsed, at Union as well as Member State level, and the observation that policy areas have become increasingly intertwined in Europe led us to conclude that the Treaties' focus on national identity is actually to be welcomed.

As a consequence, the concept of national identity should not be discarded lightly as being too vague or overly political. It is precisely the task of legal commentators to lay bare the meaning of the notion as it is employed in Article 4(2) TEU, and it is my view that in doing so they should take due account of the moral prin-

72 Cloots, National Identity in EU Law, 175-80.

73 See also Schütze, From Dual to Cooperative Federalism, 348-52. 
Elke Cloots

ciples underlying the identity clause. To be sure, this will not be an easy job. Moreover, it is only natural that legal scholars feel more comfortable with conventional legal concepts, such as constitutional identity. Yet this is no excuse for simply reading a reference to constitutional identity into Article 4(2) TEU, especially when the text of that provision does not make mention of the concept and compelling reasons exist for putting national identity, rather than constitutional identity or State sovereignty, front and centre in the Treaties. 